\title{
Gymnastics in higher education: reflections on assessment
}

CDD. 20.ed. 796.01

796.41

http://dx.doi.org/10.1590/1807-55092016000100171
Michele Viviene CARBINATTO* Myrian NUNOMURA**

\begin{abstract}
Assessment procedures were based on the traditional educational paradigms of linearity and sequence, whose aim was to categorize and select individuals. With the advancement of Social and Human Sciences, assessments gained both a reflexive and an analytical characteristic and now they constitute a system of support and guidance for individual and group learning, all without losing sight of building character in the students. Supported by qualitative research, this study identified and discussed the assessments used by 14 university lecturers in the state of São Paulo who teach Gymnastics in the Physical Education undergraduate courses. The results showed different formats of assessment, namely: theoretical; debates; practical/experience; research; self-assessment and peer-review. None of the evaluated lecturers clearly stated the assessment criteria, becoming it, mainly, subjective. Four lecturers gave indication of using the assessment tools in the formative conception and only one lecturer guides its practice during the teaching-learning process after analyzing what has been detected in assessments.
\end{abstract}

KeY WoRDs: Evaluation; Teaching; Physical activity; Educational assessment.

\section{Introduction}

The assessment of human activities has been doing even before the institutionalization of schools, having as its intent above the selection process. Initially, assessment of human activity were used as instruments in the bureaucratic processes in China for the admission of males to the offices of public service, thus becoming an instrument of social control ${ }^{1}$.

With the advent of the Medieval University as a scholastic model, the formalized and the academic written assessment with assigned grades spread and became strongly characterized as an educational practice.

Due to the public nature, in which features such as objectivity and transparency were required, the assessment had its practices structured in modern schools and took the form of written tests, thus bestowing credibility. Assessment gained a scientific quality with quantitative contours, in which standards and classification consolidated and started developing from the beginning of the 20th Century.

Precision and order became rules of assessment and the act of evaluating became the best way to regulate and build reliable knowledge. As MACEDO ${ }^{2}$ argues, the thought arises that simply to measure is to dominate, to know is to do, to explain is to understand, and understanding that "the mirage of precision rests sovereign and alone on obtaining knowledge" (p.31).

Measurement was seen as a quantitative description of reality and started to dictate the rules for assessment systems that, traditionally, sought the students' memorization of content and not the sum of abilities such as understanding, application, transference and problem-solving skills, i.e., they were focused on the final product and not on the teaching and learning process.

In order to guide and reshape the educational policy, in the late 50's of the last century, the sociological research advancement has been observed in this sector in Brazil.

Especially after the Second World War, the Brazilian Center for Educational Research ${ }^{3}\left(\mathrm{CBPE}^{\mathrm{a}}\right)$ indicated that, in times of democratizing education and socializing knowledge, there would be no more room for archaic, arbitrary, controlling and reproductive evaluation, since this method does not allow one to think the practice, but to judge it.

If we consider education as a multiple and varied experiences, to be educated is to develop and to learn to constitute the self-knowledge and autonomy.
*Escola de Educação Física e Esporte, Universidade de São Paulo, São Paulo, SP, Brasil.

**Escola de Educação Física e Esporte

de Ribeirão Preto, Universidade de São Paulo, Ribeirão Preto, SP, Brasil. 
Therefore, assessment takes an orienteering dimension and allows students to be aware of their progress and difficulties, to continue advancing in the construction of knowledge ${ }^{3}$.

Assessment must relate intrinsically to the educational process and be inserted in such a way that it values each student at its level of maturity and understanding and provides support and guidance to individual and collective learning. It also should encourage students to communicate their understanding, their questions, and to recognize themselves in the teaching-learning process ${ }^{3-6}$.

In other words, the assessment should focus the students on their progress and needs, and integrate the working process in the classroom's day-to-day life. The participation could include group activities, project discussions, and the development of tasks in order to see if the students approach the proposed concepts and skills, to see their difficulties, and then know how to help students to overcome them, and all with the possibility of finding new ways.

In this sense, the purpose of this study is to present reflections on the assessment applied by university lecturers who teach the subject Gymnastics within the State of São Paulo and to identify those which best fit the current principles of assessment ideas.

\section{Assessment as a process}

Assessments should be used as a tool during the whole learning process and the instruments to assess should be diverse, having moments of analysis, reflection, involvement, and decision-making. Both the lecturer and the student are influenced by the assessement, because the lecturer also needs to reorganize his/her planning.

It is necessary that the lecturer offers to the students with the so called "cumulative syntheses", i.e., the final moment of a period, module or course, in which it is possible to review and relate the presented content. In other words, the passage from syncretizes (initial chaotic moment, unplanned) to synthesis (final moment).

When preparing and proposing an assessment, the lecturer should be clear about what was planned, as with established goals it is implicit what is expected from the students do and how this information will be transmitted in order to analyze whether the information arrived as expected or not.

GoldBerg and SouzA ${ }^{7}$ begin the discourse on different stages of the educational evaluation (followsup the execution of the plan process. For the authors an assessment consists in the process of collecting, analyzing, and interpreting evidences of the effectiveness and efficiency of educational programs.

In this sense, the planning should consist of: diagnostic assessment (prior to the development of a plan or program); "ex ante" assessment (after the assessment of a plan but prior to its approval by a supervisor or director, for example); "in processu" assessment and controls the steps); and finally, "ex post" assessment (after the achievement of results, in order to observe what was actually achieved).

Some questions may be which principles should guide the practice of a lecturer and, in consequence, its assessment process, aiming to a professional training of quality? Which assessment processes are more specific and pertaining to the process of higher-level education?

The paradigm change in evaluation comes from speeches, which criticized the quantification of tasks performed by lecturers. Based in the emancipatory conception of education, the evaluation baptized as formative is defended as the one allowing the criticism to reality, overcoming the pedagogical immediacy and the possibility of the student questioning and reflecting on the subject of the class ${ }^{5,8-11}$.

SCRIVEN ${ }^{12}$ was the first author to use the expression "formative" when defending that the systematic observation of the lecturer would improve the class activities and warrant the students learning . Then, the evaluative speech that focused on the student only started also to question the lecturer and his/her teaching strategies.

The formative assessment, as Cipriano ${ }^{13}$ explains, starts to infer actions in the global development of the content, and considered a stage and not the routine "accountability" of the teaching-learning process. The lecturer, after evaluation moments, the lecturer must adjust the teaching situations and pedagogical interventions in the most systematic and individualized way that is possible ${ }^{14}$.

The assessment process is conducted by the lecturer and offers two feedbacks: one for the student by giving him/her more autonomy to perceive own progress and his/her possibility and fragility; and one to the lecturer, who analyzes his/her strategies ${ }^{8,10,15}$.

Also, ideally, the formal assessment task "is constructed by the assessor, keeping in mind the structure and progression of the subject's discipline (s) involved, in the appreciation of the sequencing of the intellectual and moral development progression of the students and a knowledge of the current level of intellectual development of his or her students ${ }^{16}$ (p.485). 
Unisonous to the methodological strategies of each lecturer, the formal assessment demands a set of tools, which allows him/her to get information on all domains of learning, and not only their reproduction (recognition of memorized notions).

The fundamental perspective of formative evaluation is the problematizing aiming to the constant questioning and reflection on the action. Irrespective of the format, the goal of the evaluation must always be to improve the "meaning and functionality of apprenticeships in order to allow the students to integrate the knowing with the knowing-doing, the thinking and the acting with the meaning, which will allow them to develop competencies for life"17 (p.20).

The National Council for Evaluation of Higher Education $^{3}$ appointed some goals of evaluation, especially in higher education. It highlights the following: the stimulation of the quality of the student's activities; the promotion of the capacity of identifying a problem and to solve it in the best possible way; the provision of tools of future autonomy for active insertion in society; and to recognize the importance of the evaluation in all moments of the individual formation.

The credibility of the evaluation must also be mentioned. Irrespective of being quantitative or qualitative, the criteria work as a code of conduct and ethical stance. The "Committee on Standards for Educational Evaluation"18, has standards based in four conditions of evaluation, which are:

1) Evaluation must be useful and ensure practical information needed by a given audience;

2) Evaluation must be achievable and feasible;

3) Evaluation must be performed legally and ethically;

4) Evaluation must be rigorous and the criteria established with precise information about what is judged.

It is important to consider the history of assessment in Physical Education. According to Negrini (cited by FARIA JUNIOR ${ }^{19}$ ), in Brazil, the classical methods of evaluation in that field were based on the French

\section{Method}

The present study based on qualitative research. Data were obtained by an interview with a structured script of open-ended questions and full recorded. The focus of the analysis centered on the question: "How do you assess your students?" Our intention was to detect the values and tools used method of certification: Elementary Certificate of Physical Education, Secondary Certification of Physical Education, Higher Certificate of Physical Education. In the latter, for example, physical ability as sprint and resistance running, high and long jumping, and throwing, among others were included. Each certificate has the minimum numeric data for both genders and, using these, the lecturers would analyze the development of the students. Therefore, a strong foundation of measuring physical abilities was be observed.

In the 60's, the practical and individual tests revealed those students which did or did not assimilate the learning process. At the end of this period, the inclusion of basics of health, school safety and different sport rules in the assessment system were observed. Even so, the ideal of physical performance and memorization still prevailed.

This characteristic lasted for a long time in Brazil and in fact is was adopted for the selection of students to enter Physical Education courses in the country until the beginning of this century.

Currently, it is possible to report different ways of assessing students. An appropriate assessment must start with clear objectives. However, only one type of evaluation, or even many, cannot precisely describe the complex phenomena inherent in the teachinglearning process. One must understand that each activity has its possibilities and limits and only their combination will allow more reliable conclusions ${ }^{20}$.

Metaphorically, it is possible to understand the evaluation as a compass that helps us interpreting a map in order to perform changes in the route, if necessary $y^{4}$. The evaluation is complex and dynamic, and should not be limited to measuring content retention, but to allow the political, critical and creative formation of the student.

Therefore, the questions is how do gymnastic lecturers deal with this issue? Do they base themselves on the variety of tools for assessment, and focus on the formative conception? Or, focus on the traditional processes of verifying the assimilation of knowledge?

by lecturer, because, "when evaluation is discussed, tools of verification and criteria for analysis of final performance are in fact being discussed"8 (p.34).

The non-probabilistic or intentional sampling was adopted because our interest centered on the opinion of a specific set of the population: 
the lecturers who teach gymnastics courses in the Physical Education undergraduate courses in higher education institutions of São Paulo State.

Thus, from the 29 institutions of São Paulo identified (the various campi of some were excluded), 24 included disciplines of gymnastics in their undergraduate curriculum.

In each one of these institutions, a lecturer who had been active for at least two years in higher education and for one year with a commitment of at least 20 hours per week in the institution researched was chosen; who taught at least one subject of gymnastics represented by the International Gymnastics Federation (FIG). After contacting

\section{Results and discussion}

Following are the categories and discussion of the findings.

\section{Practice}

One of the most noted lapses during the initial education of lecturers refers to excessive theoretical knowledge in the higher education, which leads to the designated "shock" with the reality, mainly due to the difficulty of relating their acquired knowledge with the real world. This situation prompted a great number of answers regarding practical assessments as well.

A brief note is necessary: the practical session here is understood as the context approximating the reality by the simulation or simplification of real projects, under careful supervision, which "incorporates specific points of view, of thought, of doing that tend to, with time, have their authority ever more reinforced in the student's point of view"22 (p.40).

Six lecturers evaluated the students on their presence in class, in a general sense, just by being there and taking part in the class. Here we ask the question: Should not participating in class be one of the duties of the learner? In fact, two lecturers make it clear about assessing the "simple" participation of students, in other words, "in the sense of attending class" (L1), "if he is attending, he is participating and not just sitting, working on a report, then he has participated and he is connecting the dots" (L6).

To avoid subjectivity, lecturer L4 argues that evaluates if the student took part or not in class, and attributes points for each moment of participation in class and that this attitude forces the student to and permissions was granted, we interviewed 14 lecturers.

The content analysis technique ${ }^{21}$ was applied as data treatment, especially in the thematic module, which assertion over a given topic can be represented by a simple sentence, a set of them or a paragraph. The technique also includes, with greater or lesser intensity, the personal aspect assigned by the respondent about the meaning of a word and/or about the connotations attributed to a concept, involving both rational elements, as well as ideological, affective and emotional ones. This study was approved by the Committee of Ethics in Research of the School of Physical Education and Sport from University of São Paulo.

experience the class, thus having greater chances of liking and understanding it better: "I do this very objectively, consequently it loses 0.20 in each class, and so in a real sense it is a way to force them to participate (...), there are things you have to force them to experience and say 'Look, there are really so many nice sensations'” (L4).

In formative conceptions, quantification alone is not considered as an evaluation and, therefore, this situation must be reviewed ${ }^{5}$.

The posture when in the role of lecturer is considered by six lecturers and includes the "class control, the voice of command and the execution of exercises" (L8), "if it is dependent on PowerPoint, how it presented the material, if it's written, if it's all on topic, if it is reading all the time" (L11). It is possible to identify an interest in observing the general education of this lecturer, and not necessarily if the knowledge and specific content of the subject were assimilated.

Lecturer L12 makes it clear as from the moment the students are lecturers, he/she offers "feedback, I say it could have been done this way, if that was cool and such". HADJI ${ }^{9}$ mentions that feedback is one of the main strategies to promote the improvement of the teaching-learning process, however, again, the criteria and moments when this feedback happens was not mentioned.

The choreographic presentations, typical of projects developed from the concept of gymnastics for all, were analyzed by six lecturers. For lecturer L2, this evaluation allowed the student to experience the "complex context of the presentation, which is 
what we define as the synthesis of everything he learned, and thus he will present it to the public, as light, as sound, as a synthesis of that work".

Some lecturers indicated that on the day of presentation, they followed an assessment guide concerning everything related to artistic evaluation: position on stage, markers, songs, wardrobe, choreographic composition - connecting human elements and formations, among others.

However, similarly to lecturer L9, there is the caution to evaluate the time prior to the presentation as well: "I observe that time I allow for them to rehearse during the class, who leads, who is helping, which one is having difficulty, the one that got together with others because they were having a problem, (...) thus I evaluate without being focused on just one specific day" (L9).

The process of assessing the composition and organization of a gymnastics festival implies observing, directly and indirectly, the students in the performance of activities more closely related to situations they will encounter in a formal study environment, for example.

Another procedure is also intrinsically associated with the methodological strategy during gymnastic competitions and it concerns the routines on the apparatuses $(n=4)$ performed by the student, in other words, "my practical evaluation includes a series of floor exercises, balance beam, uneven bars, vaulting, trampoline, horizontal bar, and even parallel bars" (L5).

While some lecturers indicate that they do not consider performance, we believe that they do not analyze perfection, but the technique inherently associated with the correct and efficient performance of the movement. It seems there is no misconception in requiring students to understand the technique. However, attention is required so the assessment is not focus on "know how" which does not necessarily leads to know how to teach or learn about the sport. A heritage of traditional teaching, the concern about reproducing a technique/content and/or acquisition of abilities emphasizes the "doing" rather than "construction" of knowledge by the student.

Lectures must attent that the obligation of the routines does not makes the students to assimilate how to teach the elements, so the activity cannot be restricted only to the skills involved in this sequence.

Both situations also allow that lecturers consider the informal aspects, also advocated by the formative evaluation ${ }^{15}$. Regarding that the interaction of the student with lecturers, colleagues and professionals of the educational environment are occasions of evaluation and allow intervention, but that should happen in a planned and systematic way.

The lecturer particularly committed to the PETE (Physical Education Teaching Education) should clearly understand the fundamentals of gymnastics, as these are the foundation for the future learning of specific skills for all gymnastics (sports and activities). And several authors advocate the diversity of motor experiences during the initial stages of the sport training ${ }^{23-25}$.

Thus, attention must be given to this method of evaluation: are we not inducing students to look at a restricted forward vision in face of the diversity that gymnastics could offer?

Another practical assessment format is related to the educational process of gymnastics $(n=2)$. In this case, the lecturers are concerned in observing the support and assistance that a student (in the position of a lecturer) offers to another student (in the position of a student). However, we noted that one of the lecturers directed his attention so that the students (playing the lecturer) could identify the physical and motor capabilities involved (strength, balance, flexibility, etc.) and not to the gymnastic skill and the specifics of this field itself. This fact is disconcerting as the student can accomplish the course without understanding the taxonomy and dynamics of gymnastics.

One of the lecturers considers both the complete action/execution of the movement and the assistance: "So during a week he performed all the right movements to be executed correctly, technically, you know? And the friend stayed by his side assisting him, so I can work both of them." (L13).

In the previously mentioned situations, we realized that almost all the lecturers reported a strong evidence of subjectivity on the assessment and were not clear about what they observed, in other words, the criteria. However, the students know they are being evaluated "at least the student knows he is being assessed" (L8). In this sense, the students know the time of assessment without necessarily knowing the criteria of that. YORKE ${ }^{16}$, GIPPS ${ }^{26}$ and SADLER ${ }^{27}$ highlight that the formative evaluation demands the previous formulation and explicitness of criteria that the lecturer will apply.

\section{Theoretical}

Among the interviewers, six used the written exam to encompass the general characteristics of the sport "from the history of gymnastics until all the knowledge about the equipment and the movements" (L1). We did not have access to these 
papers, but mostly were of alternative nature, in which the student identified certain points, in other words, memorization, and not criticize a subject. We emphasize that this activity is not unique and all the lectures made a point to clarify that other forms of assessment that did not only dealt with general subjects of the sport.

We agree with BeHRens ${ }^{28}$ about the fact that situations in the process of verification of learning can start by memorization. Nevertheless, the verification cannot be limited to them since, after all, learning must demand actions, which bring the student into the process of investigation, in other words, to know how to explore, think, and build knowledge.

None of the lectures reported to use the "review of the testing" as a way to solve doubts and observing if the question is clear or if the content should be revised.

Antônio ${ }^{29}$ reveals that it is necessary for the lecturers to organize the so called "theoretical" questions, in order to assist the students in the process of learning to delineate themes, questions, and problems. The author observed a currently, a scarcity of clarity in ideas and language can be observed and "great are the difficulties to weave coherent and expressive arguments and develop cohesiveness in phrases, paragraphs, and in the text as a whole" (p.44).

Therefore, for three lecturers these evaluations encompassed not only the specific knowledge of the material, but they also allow to verify and help the student in the ability to argue: "this theoretical test is not in the sense that they need to memorize many things, but they need to understand many things. Therefore, the answer that I want on the theoretical tests is a combination of the reading they had during the semester (...), then, a theoretical exam is a mix of this knowledge of literature along with what we debated and experienced in class, which often contradicts the literature" (L2).

The authors reported that the majority of the questions on the written work stimulate the general understanding and verify if the students are dealing with the controversies and discussions involved in the field that will permeate their daily professional lives, such as: "they need to know how to write (...), therefore, in the dissertation I look at their logic to organize their thoughts and secondly at their capacity to express their arguments, which will be so fundamental in 10 years when they speak to a student's parents, or, suppose, with journalists when they are interviewed by them, thus they need good arguments" (L2).

BEHREN $^{28}$ says that this stage of individual production gives to the students the possibility to express their opinions and present their productions based on the research shared with their colleagues. However, in the formative evaluation the mediation should be previewed, in other words, the pedagogical intervention coming from the interpretation of the tasks. None of the lecturers, after applying this instrument, reported to use improvements in the learning opportunities for the students ${ }^{16}$.

Moreira and Nista-PicCOlO ${ }^{30}$ clarify that the action towards the education of a Physical Education lecturer should involve the thinking process, which incorporates the words of MoRIN ${ }^{31}$ (p.111) "knowing how to see implies, consequently, knowing how to think, as knowing how to think implies knowing how to see. Knowing how to think is not something that is obtained by technique, formulas, or methods. Knowing how to think is not just applying logic and the verification of experiential information. It presupposes, as well, knowing how to organize the experiential information".

In proposing solutions for problem situations, a lecturer must attempt to approximate, as much as he/she can, these real everyday situations "with the understanding that the student may be prepared to critically resolve the relevant and significant situations which are presented daily in its life"28 (p.56). Lecturer 10 reported this fact: "problem issues, from a student in school, from a lecturer who has such a problem in school, in which they really must reflect, analyze everything, before they can answer".

\section{Discussions}

The assessment in the higher education should also encourage discussion, such as the posture of intellectual problematic, that originates from an understanding of contexts in which the activities will be implemented.

It is important that the assessment is the moment to place the ideas under consideration and to perform an analysis of convergent or divergent points between the students and, consequently, learning to observe the diverse facets of the same situation. For lecturer L9, "when they debate among themselves, you perceive that they have an idea, a point of view", and thus, this lecturer prefers to make that in pairs or groups, so that those discussions take place.

Lecturers L4 and L10 explained that they work with text discussion, in other words, they suggest texts for reading and they discuss topics concerning the themes with the students in the classroom. 
Seminars also appear as a proposed assessment tool. Originating from the term "seed", this proposal should favor the dissemination and germination of ideas and, it's obvious, it cannot be considered just "an occasion for the transmission or acquisition of mere information, but a source of searching and communicating information or research results" ${ }^{\prime \prime 2}$ (p.31).

In seminars students are divided in small groups and they present an article or a chapter of a book, and when possible, they create situations for debate. We emphasize the importance of the lecturer as the facilitator and instigator of these debates, as students usually contribute little to what is presented by their classmates.

For an effective debate, it is necessary that the lecturer has a guideline, as path to follow and that it addresses the pertinent topics and amplifies the capacity for argumentation, for understanding, and for debate among students.

\section{Direct participation of students in assessment}

Individualization is one precept of the formative assessment, thus being possible to provide a personal diagnostic so that the student can identify his/her its domain level and mistakes and be able to understand and deal with them ${ }^{33-35}$. Moreover, a way to fulfill this condition is by performing a self-evaluation.

Self-evaluation deals with the evaluation by the student about him/herself, the actions and learning, in which an analysis of personal progress, needs, limits, and achievements is possible to make.

In such involvement on his/her on progress the student is not only the executer of orders, but someone who has clear the goals of the discipline and the content, therefore he/she could understand the track to be followed.

Althoug it is not considered as traditional in learning institutions, it is suggested that the lecturers stimulate the students to guide their own eyes to the points which should be provided. Those points are: the performance of each one; what they have learned; what were the difficulties in the concept that they have encountered; and then they reflect on how to improve the next situation.

Lecturer L9 was the one who more closely approached the self-evaluation, even though she was speaking with regards to the correction of a specific document: a theoretical test applied previously: "Although the gymnastic test was corrected by them, I gave the test, and the following week I gave a feedback to the student, and each one kept his/her own test. 'Where is my score? Where is my score?' 'You will give yourself a grade'. I made notes on the white board regarding each question on the test. 'Now you will see what you did and on the back you will put what you think you deserve based on what you did. Afterwards I'll read your test again and evaluate to see if you deserve what you think you do.'

In this situation, a lecturer guides the discussion and the answers that would be close to the "ideal" in light of the recommended texts and what was discussed in class. We noted the fact that it is necessary to encourage the students to argue their points of view, and what the lecturer considered as self-assessment, was not strictly self-assessment, but an evaluation of a document filled out by himself/herself.

This format seemed interesting when the lecturer reported about the student who gave himself an " $F$ ", of failure, and went on to have a greater understanding of the necessity to commit himself more to the discipline: "I said, 'See, it's nice to give Fs' 'How boring lecturer' (...) and then you already start to make them aware of things, so he understands that the test really doesn't matches with anything I gave in class and with what I put on the board. His participation, which I also pay attention to, wasn't a participation level that would help him to solve that test, (...) but he didn't even get that." (L9).

We perceive that both lecturers understand selfevaluation as a unique road for the student. However, aspects coming from it can also help actions to reorganize a subject being treated in classroom.

Besides, the self-evaluation must be organized with a list of items, which were worked in classroom as well as aspects of general formation, so that the students are oriented while explaining how they had developed or understood each aspect ${ }^{8,36}$.

In peer-assessment the lecturer proposes activities in which the students will share impressions about themselves and will reflect on it, the productions and/or the actions of all to understand aspects that are common with regards to their education, will appreciate the value of production, and will talk about perspectives and points of view.

Lecturer L1 carries out the assessment between pairs and in group presentations, in which the group participants assess themselves and according to the lecturer, "conflicts are created without question, (...) we perceive a corporatism, which is common, but then they are realizing how important it is to evaluate someone (...) but how they are going to evaluate someone else becomes a concern." 
This proposal also has the advantage of mutual assistance and is conducted by the language that students normally use; but should be always monitored by the lecturer.

$\mathrm{HADJI}^{37}$ and $\mathrm{MACEDO}^{2}$ add that the evaluation, as solidary monitoring and in which there is the inclusion of the evaluated person into the process, allows the person to recognize what is assimilated and the points needed to be improved. Perhaps, those instruments are more defended by theorists of formative evaluation, because the student gradually takes responsibility by its apprenticeship, observes the developed activities or in development and identify future actions.

\section{Research}

Lecturer L3 proposes a field research as assessment. Although BeHrens ${ }^{28}$ emphasizes that research offers the student an opportunity to investigate the problem-issue and look for information from multiple resources of knowledge, the lecturer suggests to the students the simple application of a questionnaire to coaches and lecturers of gymnastic.

The answer of the lecturer is interesting, but this format of evaluation lacks more details, such as the connection between theoretical discussions and amplification of these discussions to the students of the course, for example. It seems that the potential for learning that could be created in this method is not used, as the students only act during the data collection.

We consider pertinent to emphasize that some lecturers are not completely autonomous with regards to assessment, especially those who work at private institutions in different campuses and teach undergraduate groups in Physical Education.

Lecturer L6, for example, would like to evaluate better and put more emphasis on practical evaluation forms, but is unable to do so, because "it is the university's determination that it has to be divided into 8 points for the theoretical part and 2 points for the practical part."

The same lecturer adds that the development of the theoretical knowledge test is imposed to him. At the university he works, if the discipline has 2 hours per class, 12 questions are necessary, in which $60 \%$ are multiple choice ones and $40 \%$ written questions.

In another case (L10), the assessment is made in connection with other lectures, who also teach gymnastics in different campuses at the same university. They organize it at the beginning of the academic period. Thus, the lecturer follows stepby-step the program so that the students are not harmed along the evaluation. At times, the lecturer himself emphasizes that would like to review some content again or to emphasize another topic, but he cannot, because the evaluation is scheduled and is necessary for the students to have access to all their content as previously planned.

In sum, from the three primordial principles of formative assessment, we found on the reports that:

1) Esteban ${ }^{38}$, Vianna $^{39}$ and Hoffmann ${ }^{8,10-11}$ highlight that assessment must be diversified, because apprenticeship is multi-dimensional, in other words, many opportunities to express their ideas about the subject in question must be offered for the students and, so, better observing the hypothesis under construction or constructed. This diversity was observed among the lecturers that teach gymnastics. However, only four of them indicated principles of formative evaluation about how they use those possibilities. CowIE and BeLL ${ }^{40}$ how similar findings as the assessment seemed to be conducted with lecturer-oriented requirements and small attention is given to the students consequential action.

2) If the proposal of the lecturer is that everybody learns one of the first attitudes is to inform what will be seen in class and the reason for studying that. CANEN ${ }^{41}$, LUCKESI $^{42}$ e OLIVEIRA ${ }^{43}$ also advocate the importance in presenting the criteria that will be used in the evaluation processes. For the authors, the diagnosis listed by the evaluation will depend on how the lecturer will perform the interaction with the student after the evaluation: as classificatory or with critics and suggestions for improvement and continuity of the process? Clarifying and identifying the criteria in the answered instruments help and guide the student also in studies.

3) Only one lecturer mentioned that the evaluation orient, posteriorly, the lecturer practice, contrary to inherent aspects of evaluation mentioned by EsTEBAN $^{38}$, FAZENDA et al. ${ }^{6}$, which mention that evaluation must determine continuities and ruptures in the teaching process. In the formative assessment, the student has the opportunity of constantly verifying the activities, procedures, resources and observing if the learning process is effective. In other words, adaptations are made according to the interpretation of collected information. Because, "to evaluate consists, essentially, in determining the extent to which the predicted goals are really being reached" ${ }^{\prime 44}$ (p.29).

The student must manage his/her own apprenticeship, experimenting and living situations 
and being part of the process in order to learn. The lecturer must help the student to reflect on and think about the objectives proposed to it.

In this point, $\operatorname{SADLER}^{27}$ (p.77) observes that "substantial modification to the learning environment by changes to the regular classroom practice involves turning the learning culture around".

All lecturers had more than one assessment format in a same discipline, something that we consider a great advancement and represents greater opening for new possibilities. However, we observe a certain instrumentation of the evaluation and not reflection on and changes in the pedagogical action and consequent increased autonomy of the student in this process. Besides, the observation and evaluation criteria were not well allocated, and giving us the impression of subjective analysis models.

Four lecturers indicated evidence of evaluation as a thermometer and not as a ranking tool for the students, according to lecturer L9: "then, my biggest concern with Physical Education students is having them learning during the whole process, that they are not worried with the testing or with an evaluation, trying to have a score". But, none of the lecturers change or reorganize the discipline according to what they find during the evaluation moments.

Assessment must be considered in two aspects: provisional and complementarity. The first one expresses that the student's answer is the starting point of new challenges for the lecturer. The second one defends that new observations will allow to better understand the ongoing process, and be used to complement the observation of the process ${ }^{8,10-11,26,33}$.

Accomplishing the formative assessment is not only technical, but also political, because it supports a project of the society in which the cooperation, inclusion, emancipation, and reconstruction of knowledge are considered.

\section{Note}

a. The Brazilian Center for Educational Research (CBPE) was organized in four autonomous divisions: educational research, social research, educational documentation and information and master's improvement.

\section{Resumo}

Ginástica no ensino superior: reflexões sobre avaliação

Os processos de avaliação tradicionais pautavam-se nos paradigmas educativos de linearidade e encadeamento, cujo objetivo era classificar e selecionar os indivíduos. Com o avanço do discurso das Ciências Humanas e Sociais, a avaliação ganhou um caráter reflexivo e analítico, e passou a se constituir em um sistema de apoio e orientação para as aprendizagens individuais e coletivas, e sem perder de vista a formação pessoal dos alunos. Apoiado na pesquisa qualitativa, o presente estudo identificou e discutiu as avaliações utilizadas por 14 docentes universitários do Estado de São Paulo que ministram as disciplinas de ginástica nos cursos de licenciatura em Educação Física. Os resultados evidenciaram diferentes formatos de avaliação, quais sejam: teórica; debates; prática/vivência pesquisa; autoavaliação e avaliação entre pares. Nenhum dos docentes esclareceram claramente os critérios de avaliação, ficando a mesma, sobretudo, subjetiva, quatro docente apontaram indícios de utilização dos instrumentos avaliativos na concepção formativa e apenas um docente orienta sua prática durante o processo de ensino-aprendizagem, após analisar o que foi detectado nas avaliações.

Palavras-chave: Avaliação; Docência; Atividade física; Avaliação educacional. 


\section{References}

1. Fernandes CMB, Zanchet BMB, Leal A, Menetrier MM, Azevedo MA. Formatos avaliativos: trajetória histórica, contradiçóes e impactos em estudantes universitários. In: Cunha MI. Formatos avaliativos e concepção de docência. Campinas: Autores Associados; 2005. p.143-62.

2. Macedo RS. Chryssallís, currículo e complexidade: a perspectiva crítico-multirreferencial e o currículo contemporâneo. Salvador: EDUFBA; 2002.

3. Centro Brasileiro de Pesquisas Educacionais. Os estudos e as pesquisas educacionais no Ministério da Educação e Cultura. Educ Ciênc Soc. 1956;1:5-60.

4. Smole KCS. Textos em matemática: por que não? In: Smole KCS, Diniz MI, organizadores. Ler, escrever e resolver problemas: habilidades básicas para aprender matemática. Porto Alegre: Artmed; 2001.

5. Boughton D, Cintra AHR. Avaliação: da teoria à prática. In: Barbosa AM, organizador. Arte/educação contemporânea: consonâncias internacionais. São Paulo: Cortez; 2005.

6. Fazenda I, Kieckhoefel L, Pereira L, Soares AZ. Avaliação e interdisciplinaridade. R. Interd. 2010;1:24-37.

7. Goldberg MA, Souza C. A prática da avaliação. São Paulo: Cortez \& Moraes; 1979.

8. Hoffmann J. O jogo do contrário em avaliação. Porto Alegre: Mediação; 2005.

9. Hadji H. Avaliação desmitificada. Porto Alegre: Artmed; 2001.

10. Hoffman J. Avaliação mediadora: uma prática em construção da pré-escola à universidade. Porto Alegre: Mediação; 2000.

11. Hoffman J. Avaliação: mito ou desafio: uma perspectiva construtivista. Porto Alegre: Mediação; 1991.

12. Scriven M. The methodology of evaluation. In: Tyler RW, Gagne RM, Scriven M, editors. Perspectives of curriculum evaluation. Chicago: Rand McNally; 1967. p.39-83.

13. Cipriano E. Avaliação, espinha dorsal do projecto político-pedagógico. In: Melo MM, organizador. Avaliação na educação. Pinhais: Melo; 2007. p.69-85.

14. Perrenoud P. A prática reflexiva no ofício de professor: profissionalização e razão pedagógica. Porto Alegre: Artmed; 2007.

15. Villas Boas BMF. Portfólio, avaliação e trabalho pedagógico. Campinas: Papirus; 2004.

16. Yorke M. Formative assessment in hight education: moves towards theory and the enhacement of pedagogic practice. Higher Educ. 2003;45:477-501.

17. Gonçalves F, Albuquerque A, Aranha A. Avaliação: um caminho para o sucesso no processo de ensino e de aprendizagem. Castelo da Maia: ISMAI; 2008.

18. Joint Committee on Standards for Educational Evaluation. Program evaluation standards statements. Boone: JCSEE; 2013. Available from: http://www.jcsee.org.

19. Faria Junior AG. Fundamentos pedagógicos da educação física. Rio de Janeiro: Ao Livro Técnico; 1986.

20. Krasilchic M. Planejamento educacional: estruturando o currículo. In: Marcondes E, Gonçalves EL, editores. Educação médica. São Paulo: Sarvier; 1998. p.5-9.

21. Bardin L. Análise de conteúdo. Lisboa: Ediçóes 70; 2010.

22. Schön D. Educando o profissional reflexivo. Porto Alegre: Artmed; 2000.

23. Barbanti VJ, Tricoli V. A formação do esportista. In: Gaya A, Marques A, Tani G, organizadores. Desporto para crianças e jovens: razões e finalidades. Porto Alegre: UFRGS; 2004. p.199-216.

24. Estriga ML. Escola de desporto: um modelo de formação e orientação desportiva. Porto: Horizonte XVI; 2000.

25. Estriga ML, Maia J. Um estudo exploratório com treinadores e docentes de voleibol sobre a orientaçấo desportiva de crianças e jovens. In: Mesquita I, Moutinho C, Faria R, editores. Investigações em voleibol: estudos ibéricos. Porto: FCDEF-UP; 2003. p.210-20.

26. Gipps CV. Beyond testing: towards a theory of educational assessment. London: Farmer; 1994.

27. Sadler DR. Formative assessment: revisiting the territory. Asses Educ. 1998;5:77-84.

28. Behrens MA. Paradigma da complexidade: metodologia de projetos, contratos didáticos e portfólios. Petrópolis: Vozes; 2008.

29. Antônio S. Educação e transdisciplinaridade: crise e reencantamento da aprendizagem. Rio de Janeiro: Lucerna; 2002.

30. Moreira WW, Nista-Piccolo V. Formação de professores de educaçáo física e o projeto pedagógico da escola: a busca do pensamento complexo. In: Bento JO, Tani G, Prista A, editores. Desporto e educaçáo física. Porto: Universidade do Porto; 2010. p.75-83.

31. Morin E. Para sair do século XXI. Rio de Janeiro: Nova Fronteira; 1986.

32. Vieira RM, Vieira CV. Estratégias de ensino/ aprendizagem. Lisboa: Horizontes Pedagógicos; 2005.

33. Boud D. Assessment and learning: contractory or complementary? In: Knight P, editor. Assesment for learning in higher education. London: Kogan Page; 1995. p.35-48.

180 • Rev Bras Educ Fís Esporte, (São Paulo) 2016 Jan-Mar; 30(1):171-81 
34. Biggs J. Teaching for quality learning at university. Buckingham: SRHE and Open University; 1999.

35. Knight P. The value of a programme-wide approach to assessment. Assess Eval High Educ. 2000;25:237-51.

36. Black P, Willian D. Assessment and classroom learning. Assess Educ. 1998;5:7-74.

37. Hadji C. É preciso apostar na inteligência dos alunos. Nova Esc. 2006;198:17-20.

38. Esteban MT. Avaliação: uma prática em busca de novos sentidos. Rio de Janeiro: DP\&A; 1999.

39. Vianna HM. Avaliação educacional: teoria, planejamento, modelos. São Paulo: IBRASA; 2000.

40. Cowie B, Bell B. A model of formative assessment in science education. Assess Educ. 1999;6:101-16.

41. Canen A. Avaliação diagnóstica: rumo à escola democrática. Rio de Janeiro: Fundação Roquete Pinto e TVE; 1997. (Série XII Ensino Fundamental: Programa um salto para o futuro).

42. Luckesi C. Avaliação da aprendizagem escolar. São Paulo: Cortez; 2000.

43. Oliveira CC. Dimensão instrumental da avaliação. In: Berbel NAN, Costa WS, Gomes IRL, Oliveira CC, Vasconcellos MMM, organizadores. Avaliação da aprendizagem no ensino superior: um retrato em cinco dimensôes. Londrina: EDUEL; 2001. p.17-28.

44. Haydt RC. Avaliação no processo ensino-aprendizagem. São Paulo: Ática; 1997.

\begin{tabular}{|c|c|}
\hline $\begin{array}{r}\text { ENDEREÇO } \\
\text { Michele Viviene Carbinatto } \\
\text { Departamento de Esporte } \\
\text { Escola de Educação Física e Esporte - USP } \\
\text { Av. Prof. Mello Moraes, } 65 \\
\text { 05508-030 - São Paulo - SP - BRASIL } \\
\text { e-mail: mcarbinatto@usp.br }\end{array}$ & $\begin{array}{l}\text { Recebido para publicação: 01/11/2015 } \\
\text { Aceito: 04/12/2015 }\end{array}$ \\
\hline
\end{tabular}

